\title{
Inorganic and Hybrid Polymers as Evolution of Polymer Materials Science
}

\author{
Shaulov A Yu* \\ Semenov Institute of Chemical Physics, Russian Academy of Sciences, Moscow, Russia
}

Submission: July 17, 2018; Published: August 03, 2018

*Corresponding author: Shaulov A Yu, Semenov Institute of Chemical Physics, Russia, Email: ajushaulov@yandex.ru

\section{News}

Nonmetallic materials, which are widely used, have for the most part the polymer nature. These materials include hydrocarbon polymers and inorganic high-molecular compounds that do not contain hydrocarbon groups. Every class of polymers has a number of advantages and disadvantages that requires specific problems to be solved.

Inorganic polymers comprising up to $80 \%$ of the Earth's crust involve mono elemental polymers $\left(C_{n}, S_{i n}, G_{e n}, P_{n}, B n, A_{s n^{\prime}}, S_{b n^{\prime}}, B_{i n}\right.$, $\mathrm{T}_{\mathrm{en}}, \mathrm{S}_{\mathrm{en}}, \mathrm{S}_{\mathrm{n}}$ ), polyoxides, borides, nitrides, silicides, phosphides, carbides. Polyoxides (silicates, phosphates, aluminates, borates, germanates, titanates, complex polyoxides - clays, etc.) present the most widespread class of inorganic polymers, which is of greatest interest from the point of view of synthesis, properties, and the possibility of wide application.

Inorganic polyoxides have a number of important properties: incombustibility, high thermal and radiation stability, high chemical activity, extremely low vapor pressure in the molten state, environmental safety and raw materials availability. Low temperatures of synthesis and processing as well as the solubility in water of some polyoxides predetermine the possibility of polymerization under "mild" conditions, chemical modification by hydrocarbons and co-processing with organic polymers.

Another feature of inorganic polymers, particularly, of some polyoxides is the presence of the planar structure, which is not typical of organic and organometallic polymers, that implies the properties different from those of linear and crosslinked polymers. "Low-melting" oxides of various compositions with the predominant content of one of the basic elements B, P, Sn, $\mathrm{Pb}, \mathrm{F}, \mathrm{Bi}, \mathrm{V}, \mathrm{Mn}$ are used as oligomer compounds with $\mathrm{T}_{\text {soft }}=60$ $250^{\circ} \mathrm{C}$.

These oligomers, which are a new class of oligomers and thermoplastics, are synthesized by solution and "extrusion" methods at $\mathrm{T}=25-250{ }^{\circ} \mathrm{C}$ and have $\mathrm{T}_{\text {soft }}$ and $\mathrm{T}_{\text {flow }}$ like those for organic polymers, which makes it possible to use the traditional methods of synthesis, modification and processing of plastics. On the basis of oligomers, thermal resistant polymers, coatings, adhesives and reinforced composites were obtained by heat treatment and with the use of crosslinking agents. Mixtures of oligomer oxides with organic polymers represent a new class of flame-retardant composites, in which polyoxides can play the role of softening filler that makes it possible to obtain high-filled composites, avoiding rheological problems arising from their extrusion blending.

The possibility of obtaining polymer mixtures at molecular and nano levels as well as fiber formation on casting is shown accompanied by an increase in the strength of composites by a factor of 2 and in the Young's modulus by a factor of 12 . The effects of orientation of boron polyoxide having a planar structure in the melt flow in the presence of polyethylene accompanied by an anomalous change in the rheological properties of the melts as well as fibrillation in the region of the percolation ratios of the components were detected. The incombustibility of polyoxides and low vapor pressure of polyoxide melts allow one to use them for the development of non-combustible materials that do not produce degradation products in fires that is impossible when using organic polymers.

The high chemical activity of hydroxyl groups of polyoxides not only allows their modification by organic compounds, but also increases the thermal stability of some organic polymers accompanied by a change in the reaction paths of polymer degradation that allows one to consider them as high-temperature antioxidants. Polyoxides contribute to low-temperature carbonization of hydroxyl-containing polyhydrocarbons. An efficient method for controlling the rate of polyoxide polycondensation as well as increasing the hydrolytic stability of polymers and composites via addition of nitrogencontaining compounds is proposed. With quantum chemical calculations and computer simulation, the mechanism of the processes is considered. The inorganic compositions have been developed that allow the use of traditional technologies for materials molding: extrusion, casting, pressing.

There is a huge human and material damage from combustion of organic polymers, which is accompanied by the release of harmful products of thermal degradation. Another 
significant drawback of organic polymer products is a longterm assimilation of their wastes in nature, which requires considerable effort in their disposal and, finally, the need in harmful organic solvents. It can be argued that materials based on hybrid polymers and inorganic composites, the synthesis and processing technologies of which are based on the use of water are completely devoid of these shortcomings. It seems, it is high time to return to the Stone Age.

This work is licensed under Creative Commons Attribution 4.0 License DOI: 10.19080/AJOP.2018.01.555567

\section{Your next submission with Juniper Publishers will reach you the below assets}

- Quality Editorial service

- Swift Peer Review

- Reprints availability

- E-prints Service

- Manuscript Podcast for convenient understanding

- Global attainment for your research

- Manuscript accessibility in different formats

( Pdf, E-pub, Full Text, Audio)

- Unceasing customer service

Track the below URL for one-step submission https://juniperpublishers.com/online-submission.php 